\section{Commentaries from professor Herbert Hendin, April 2007}

W hen I conducted my studies in Denmark, Sweden, and N orway in the 1960s, the Swedish and Danish rates (about 20/100,000) were almost three times the $\mathrm{N}$ orwegian rate (about 7.5/100,000) and had been so throughout the $20^{\text {th }}$ century. The differences in the rates remained if one compared the sexes, various age groups, and rural and urban areas. There were those who questioned the reliability of the $\mathrm{N}$ orwegian figures. I recall at a meeting several Danish doctors advancing the theory that unhappy N orwegians were more likely to have emigrated to the U nited States and probably killed themselves there. Fortunately, U.S suicide statistics provided information on the decedent's country of origin and the same three to one ratio applied when one compared first generation immigrants from Denmark and Sweden with those from N orway.

I found striking differences in culture and character in the three countries, differences that were reflected in their fiction, popular culture, and folklore. The differences by themselves could not explain the suicide rates since they were shared by patients and non patients in the each of the countries. They did seem partially to explain differences in the psychology and motivation for suicide that I observed.

I was asked by Dr. Thorvik what I think could be responsible for the fact that while the Danish and Swedish rates remained the same, the $\mathrm{N}$ orwegian rate, particularly for men has risen to the same level as the Danish and Swedish rates. Since I have not followed the problem of suicide in the Scandinavian countries, I can't speculate specifically about N orway. Comparable increases in the same time period, however, have been observed in a number of countries that traditionally had low suicide rates - I reland, Korea, and $C$ hina are examples. They share in common a rapid increase in the pace of industrialization with a movement of young people from rural areas to the cities where economic opportunities are greater. The rise in suicide in all these countries is most marked in those who remain behind in the rural areas; those who do not do well in the urban areas are also thought to be vulnerable. From what I read N orway has experienced comparable economic growth in the past thirty years accelerated by the contribution of the offshore oil industry. The rural rates in N orway al so appear to be higher than the urban rates. So rapid an increase in suicide rates is likely to be influenced by psychosocial factors. Rapid economic expansion is such a factor and must be considered.

H erbert H endin, M.D. is CEO and M edical Director of Suicide Prevention International, Professor of Psychiatry at $\mathrm{N}$ ew York M edical College, and one of two U.S. advisors on suicide prevention to the $W$ orld $\mathrm{H}$ ealth O rganization (W H O). He has won international recognition for his studies of suicide in differing cultural contexts in Europe and with A frican A mericans, Vietnam veterans, college students, and the elderly in the $U$ nited States. Studies he did of assisted suicide in the $\mathrm{N}$ etherlands and the $\mathrm{U}$ nited States were cited by the U.S Supreme Court in its landmark decision that there was no constitutional right to assisted suicide.

$\mathrm{H}$ endin was the founding director of the A merican Foundation for Suicide Prevention and left a year ago to become CEO and Medical Director of Suicide Prevention International, an organization formed to bring advances in our knowledge of how to prevent suicide to places where the ben efits of that knowledge are not available.

\section{Vi gratulerer}

Ingrid Melle fikk Helse Øst forskningspris 2006

Ingrid M elle er seksjonsoverlege ved Seksjon for psykoseforskning på U Ilevål universitetssykehus H F og fikk prisen i kategorien Psykisk helse og rus. D et er hel seforetakene selv som har nominert kandidater til forskningsprisen. Det var plukket ut fire kandidater, og etter en hel hetlig vurdering av viten skapelig kval itet, relevans og aktualitet i forhold til forskningsstrategien til H else $\varnothing$ st gikk prisen for årets forskningsartikkel for 2006 i kategorien Psykisk hel se og rus til Ingrid M elle og medforfattere for artikkelen "Early detection of the first episode of schizophrenia and suicidal behavior". A rtikkelen viser at det å komme tidlig til i forhold til behandling av psykoser reduserer risikoen for sel vmordsforsøk.

- D ette er en anerkjennelse av jobben som er gjort, og det er ekstra hyggelig fordi dette har vært et samarbeid med andre norske sykehus og de kliniske avdelingene i Psykiatrisk divisjon på U Ilevål. Det er basert på det praktiske arbeidet som gjøres i avdelingene og den behandlingsrettete delen av virksomheten vår, sier M elle.

I fagkomitéens begrunnelse står det bl.a.: U ndersøkelsen er gjort med en original og elegant design. Selve gjennomføringen av studien må ha vært krevende både fordi undersøkelsen omfatter store områder og mange personer og fordi den har pågått i lang tid. Problemstillingen er svært aktuell og funnene har store potensielle konsekvenser for hvordan informasjon om og diagnostikk av psykiske lidelser bør organiseres. Selve artikkelen er kortfattet og vel skrevet. Denne studien viser hvordan effekten av forebyggende tiltak kan evalueres på en vitenskapelig måte. Studien bør inspirere til tilsvarende effektstudier av kampanjer og populasjonsrettede tiltak.

Mer info: www.ulleval.no - N yhetsarkiv

Referanse: M elle I, Johannesen JO, Friis S, $\mathrm{H}$ aahr $\mathrm{U}$, Joa I, Larsen TK, O pjordsmoen S, Rund BR, Simonsen $E$, Vaglum $P, M$ CG Iashan $T$. Early detection of the first episode of schizophrenia and suicidal behavior.

A m J Psychiatry. 2006 M ay;163(5):800-4

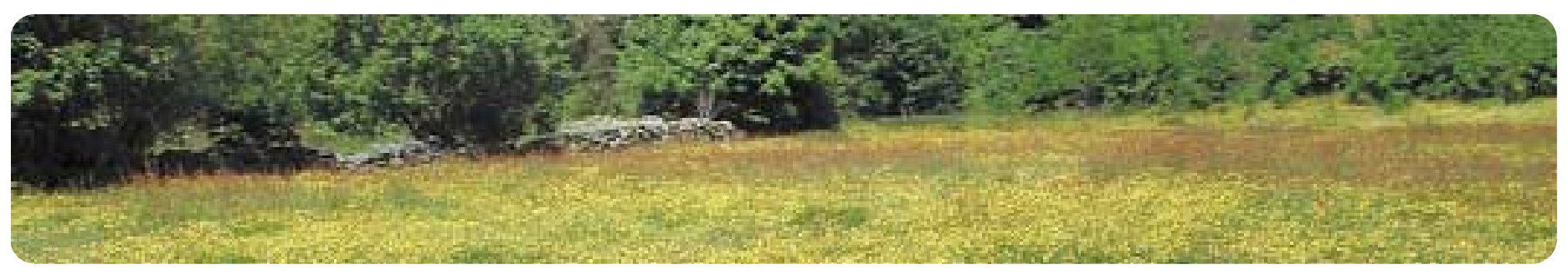

